\title{
Black Pepper Consumption in the Roman Empire
}

\begin{abstract}
During the Roman Imperial period huge quantities of black pepper arrived into the Empire from southern India and were employed in a range of contexts, from the culinary and medicinal, to the religious. This article seeks to examine the popularity of black pepper in the Roman Empire and test the theory that its consumption was not simply restricted to elite circles, but reached a wider spectrum of the population. In particular, price and wage data from the Edict of Maximum Prices is examined to see how feasible it was for those lower down the socioeconomic spectrum to make such purchases.
\end{abstract}

Sous le Haut-Empire, une enorme quantité de poivre noir est arrivée dans l'Empire romain depuis le sud de l'Inde et qui était utilisée dans divers du contexte culinaire et médicamenteuse aux religieux. Cet article cherche à examiner la popularité du poivre noir dans l'Empire romain et à tester la théorie selon laquelle sa consommation ne se limitait pas seulement aux cercles d'élite, mais a atteint un plus large éventail de la population. En particulier, les données sur les prix et les salaires de L'édit du Maximum sont examinées pour voir dans quelle mesure il était possible pour ceux qui descendent le spectre socioéconomique de faire de tels achats.

Keywords: black pepper, consumption, Roman Empire

\section{Introduction}

Goods have been exchanged between civilisations in Africa, Europe and Asia with varying degrees of frequency since at least the third-second millennium BCE, as is clear from links between the Harappan culture of the Indus valley region and the Mesopotamian world, and 
those between Egypt and the so-called land of Punt - probably not a fixed region, but one that may broadly refer to areas of East Africa above the horn or the southern Arabian peninsula (Smith 2009; Ray 2015; Keay 2005). Spices and aromatics from South Asia may well have been making their way westward before they start to be mentioned by writers like Herodotus (3.107-11) from the mid-fifth century BCE. ${ }^{1}$ Notably, Gilboa and Namdar identified traces of cinnamaldehyde from 10 Phoenician flasks (early Iron Age) found in Israel - an organic compound occurring naturally in the Cinnamomum plant group (2015: 265-83). ${ }^{2}$ In the case of black pepper (Piper nigrum), attestation of its use may go as far back as reign of Ramesses II (r. 1279-1213 BCE) for it is possible that grains were used in his mummification (Gilboa and Namdar 2015: 272).

Acknowledging such earlier movements of goods, it is also clear that the early centuries of the first millennium CE saw a substantial growth in the interconnections between Europe, Africa and Asia, particularly as a result of Indian Ocean trade. This is demonstrated not only from literary sources, but also from an expanding corpus of written (epigraphic, papyrological) and archaeological evidence derived from numerous international sites. In fact, it has become increasingly fashionable to characterize this trade as an early form of globalisation, or as Seland has called it "oikoumenisation" (Seland 2008: 70-1; Seland 2010: 18-20; Seland 2014: 386-7; 84-5; Ray 2015: 208-9). Similarly Van der Veen and Morales (2017) have recently discussed

\footnotetext{
${ }^{1}$ Henceforth all dates are CE unless specified otherwise or specific years are given. For an outline the periods referred to in the article see Appendix 1.

${ }^{2}$ Gilboa and Namdar note that the Cinnamomum species are all native to South and Southeast Asia, and hence the traces of cinnamaldehyde must ultimately have derived from cinnamon plants in these regions. However, as is outlined below, there is some debate as to whether the product that the Greeks new as кıvó $\mu \omega \mu$ ov (kinamōmon) in fact derived from a plant growing in East Africa or Arabia. De Romanis (1996: 33-70) has made the case for this view on the basis of etymological analysis.
} 
the importation of spices and the transplantation of plants during the Roman and Islamic periods at Myos Hormos/Kusayr (modern Quseir al-Qadim) in terms of food globalisation (more pronounced in the latter period).

The Roman Empire was connected into this Indian Ocean trading sphere through two major routes, the Egypt-Red Sea route and the Mesopotamian-Persian Gulf route. The latter was under the auspices of the Parthian Empire, via its vassal kingdom Characene. ${ }^{3}$ A quite significant number of Eastern products entered the Roman Empire via the MesopotamianPersian Gulf route, although most "Roman" merchants were not directly involved beyond the reception of goods at its western end - Palmyrene merchants being a notable exception. ${ }^{4}$ The Egypt-Red Sea route, however, saw direct participation by financiers and merchants from the Roman Empire. This route entailed the movement of goods and people along the Nile between Alexandria and Koptos, transport via the Eastern Desert between Koptos and the Egyptian Red Sea ports (principally Myos Hormos and Berenike, near modern Foul Bay, south of Ras Banas), sailing through the Red Sea and Gulf of Aden, and the use of the seasonal south-western and north-eastern monsoon winds to make outbound voyages to and return voyages from India

\footnotetext{
${ }^{3}$ Some scholars hold the view that Characene may have come under Roman protection as a result of Trajan's Parthian campaign (115-117 CE) and remained so up until 151 CE - Bowersock 1989; Bernard 1990; Young 2001: 143-8. However, Gregoratti (2011: 219-24) is of the opinion that after the Romans withdrew (117 CE) the Parthian ruler Vologases III punished his erstwhile vassal, replacing the Hyspaosinid rulers with members of his own Arsacid family.

${ }^{4}$ The limited detail from the mid-first century merchants' guide, known as the Periplus Maris Erythraei (henceforth Periplus) is usually cited as evidence for a lack of "Roman" involvement. See Potts 1990: 2-6, 10-12, 20-2; 120-1; Rougé 1988: 41-4. On the quite sizeable Palmyrene involvement in trade via this route see Seland 2016.
} 
(Casson 1984: 39-47; Casson 1989; Cobb 2014: 89-116). ${ }^{5}$ Merchants from the Roman Empire were operating alongside many other merchants from East Africa, Arabia, Persia and India.

It was in this context that a huge array of eastern goods were imported into the Roman Empire, among them precious gems, pearls, cotton and silk textiles, and various spices and aromatics. These were exchanged for a range of Roman products, such as wines, red coral (corralum rubrum), crafted-wares (especially glass-wares and bronze-wares), jewellery and gold and silver. ${ }^{6}$ There is no precise statistical information but it is often assumed that spices and aromatics were one of the most important groups of eastern imports, black pepper being chief among them (Warmington 1928: 181-2; Raschke 1975: 245; Raschke 1978: 650; Dalby 2000b: 195). They were put to a whole range of uses (cuisine, perfumes, dyes, medical compounds, incense mixtures) and employed in a whole host of important social contexts, from banquets to religious and funerary rituals. This has led some to argue that unlike precious gems, pearls and silks, they should be understood as necessities, at least 'by Roman aristocratic standards', if not also by those lower down the social scale (Sidebotham 1986: 45, 176). ${ }^{7}$ In addition, these aromatics and spices were usually much cheaper than other imports, at least in

\footnotetext{
${ }^{5}$ For a comparison of the Egypt-Red Sea and Mesopotamian-Persian Gulf routes see Seland 2011: 398409. For Myos Hormos - occupied from at least the second century BCE up to the third century CE see Peacock and Blue 2006; and Peacock and Blue 2011. For Berenike - occupied from the third century BCE up to the sixth century CE - see Sidebotham 2011; Sidebotham and Wendrich 2007; Sidebotham and Zych 2011; Sidebotham and Zych 2016.

${ }^{6}$ For discussion of this trade see, among other works, Warmington 1928; Raschke 1978; Sidebotham 1986; Sidebotham 2011; Suresh 2004; Tomber 2007; Tomber 2008; McLaughlin 2010; Cobb 2015 a. ${ }^{7}$ Sidebotham (2011: 249-51) has subsequently advocated the view that these spices and aromatics were consumed by a wide range of the Roman Empire's population, making them necessary for a significant number of people.
} 
relative terms: one might contrast an opal ring that Pliny reports (c. 70s CE) was valued at 2,000,000 sestertii to his statement that black pepper (Piper nigrum) sold for four denarii (sixteen sestertii) a libra (Roman pound $=323 \mathrm{~g}) .{ }^{8}$ These price differentials have led some to claim that a wider spectrum of the population could have afforded products like black pepper and incense, at least occasionally and in small quantities (Young 2001: 222-3; McLaughlin 2010: 144-5; Sidebotham 2011: 225; Van der Veen 2011: 70; Purcell 2016: 75).

The purpose of this article is to examine the evidence for the popularity of black pepper and to test the theory it was affordable for a wide spectrum of the Roman population. In order to achieve these aims the article is split into three main sections. The first deals with the challenges posed by the evidence and the approach taken in quantifying purchasing power. The second section examines what the literary evidence can tell us about the manner in which pepper was consumed and how it was perceived in Roman society, as well as considering the diffusion of black pepper finds in the archaeobotanical record. In the final section price and wage data from the Roman Empire are quantified in order to assess how feasible it may have been for different socio-economic groups to have made purchases of black pepper. It is argued that while black pepper was an exotic commodity that could imbue a sense of lavishness, especially when used in copious quantities, it was not exclusive to the elite, and in a number of senses, falls short of being a "luxury" item. It is further suggested that many beyond the circles

\footnotetext{
${ }^{8}$ Pliny Natural History 12.14.26-9 (black pepper), 37.21.81-2 (opal ring). For Roman currency values during the Principate see Table 1.1 (for those in $301 \mathrm{CE}$ see Table 1.2). For Roman weights see Table 2. The estimate of $323 \mathrm{~g}$ for a libra is used here based on Duncan-Jones' assessments of Roman weights from the Naples region - Duncan-Jones 1982. Estimates vary from 323-327g, but it is unrealistic to expect consistency across the Roman Empire down to the level of a one-tenth or one-one hundredth of a gram. The following is used here: $323 \mathrm{~g}$ for a libra, $27 \mathrm{~g}$ for an uncia (one-twelfth of a libra) and $1.12 \mathrm{~g}$ for a scruple (scrupulum, one-twelfth of an uncia).
} 
of the elite could have afforded black pepper, although these were mostly better off residents of larger urban centres or members of the military, with most of the rural poor having little direct experience of black pepper.

\section{Methodological issues: Identification, Description and Scale}

Several potential problems arise when studying the import of eastern plant products into the Roman Empire. First of all, ancient literary testimony about exotic plants and their parts (stalks, leaves, roots, seeds) are not always as detailed and consistent as might be wished, creating varying levels of difficulty in identification (Czarra 2009: 9; Dalby 2000a: 156; Keay 2005: 36; Cappers 2006: 1-2). ${ }^{9}$ For example, the description of cardamom made by several ancient authors seems to indicate that it is equivalent to its modern designation, whereas the identification of amomum has proved more contentious (Dalby 2000a: 102). Locating the source of cultivation for some of these plants can also be challenging. This is notably the case with cassia, cinnamon, and ginger where it is uncertain if these spices were transhipped to various ports, whether the species were transplanted from South Asia to East Africa or Arabia (subsequently dying out), or should be understood as different from their modern namesakes. ${ }^{10}$ The procurement of many spices and aromatics from major emporia rather than their regions of cultivation can exacerbate this confusion, as is the case with cinnamon, cassia and nard which were often (erroneously) believed by Graeco-Roman authors to originate in Southern Arabia (for example, Agatharkhides 99b + c = (b) Diodorus Siculus Library of History 3.46.1-

\footnotetext{
${ }^{9}$ For the problem of assigning names, and subsequent revisions see Gledhill 2008: 1-3, 11.

${ }^{10}$ Casson 1989: 122-4 (first theory); Dalby 2000a: 21-6 (ginger - middle theory), 36-41, 156-7 (first theory in case of cinnamon and cassia); Groom 1981: 85 (later theory); Keay 2005: 44 (first theory); Miller 1969: 42-7, 74-7 (first theory); Seland 2010: 40-1 (latter two theories); Raschke 1978: 652-5 (latter theory). For a critique of the latter two theories see Gilboa and Namdar 2015: 265-6.
} 
5 (c. first century BCE) = (c) Strabo Geography 16.4 .19 (early Julio-Claudian period); Dioscorides Materia Medica 1.12 (mid to late first century); Statius Silvae 4.5.30-2 (Flavian period); Arrian Anabasis 7.20 (early second century)).

In the case of pepper it is necessary to distinguish references in the literary sources to two species, Piper nigrum (from which both black and white pepper derive) and Piper longum (long pepper), as well as the methods of preparation, white pepper being a more ripened form of Piper nigrum. It appears that many Graeco-Roman authors were able to identify these differences, no doubt, because black pepper looks quite distinct: when unripe (often still green) fruits of the Piper nigrum plant are harvested and then sun-dried producing a distinct black and wrinkled form (Miller 1969: 80-1; Cappers 2006: 5, 111; Ciaraldi 2007: 171; Van der Veen 2011: 41). As early as the beginning of the Hellenistic period Theophrastus (EIP 9.20.1) was able to describe the differences between the two pepper species (Piper nigrum and Piper longum). ${ }^{11}$ By the time of the Periplus (mid-first century) - a unique document providing detailed information on the goods available at various Indian Ocean ports - merchants were using well-established trade routes to acquire pepper from ports near to their source of cultivation. For black pepper they went to the ports of the Malabar Coast, since, as the author noted, it was only grown in the nearby Kottanarikê region (Piper nigrum grows in the hills of the Western Ghats); for long pepper they went to northwest India. ${ }^{12}$ South Indian poetry also noted the arrival of westerners who came with gold and departed with pepper (Tayan-Kannanar Agam 149.7-11). Around the same period Pliny was also able to clearly distinguish the different

\footnotetext{
${ }^{11}$ If Athenaeus is to be believed, Diphilus of Siphnus mentions the use of pepper as a condiment as early as the early-third century BCE - Athenaeus 90f; Dalby 2000b: 65.

12 Periplus 49 (north-western port of Barygaza), 56 (south-western ports of Muziris and Nelkynda/Bekarē); Miller 1969: 80; De Romanis 1996: 178-83; De Romanis 2015: 134, 142-3.
} 
pepper products (black, white and long), although he seems to garble his botanical descriptions of these plants (Pliny Natural History 12.14.26-8). For medical writers they often made distinctions between the different types of pepper being employed in a drug compound, evidently because each product had its own distinct quality and uses (for example, Celsus $D e$ Medicina books 5 and 6 (c. first-half of first century)).

Even when the sources only mention pepper without a specific designation (black, white, long), it can reasonably be assumed that they are referring to black pepper given its popularity and importance. For example, when the author of the Periplus refers to long pepper (peperi makron) he specifically designates it as "long", whereas when he is referring to the acquisition of black pepper at ports like Muziris he does not use an adjective to distinguish it (he just uses the term peperi). Likewise in the Late Antique cookbook De re coquinaria, which contains over 480 recipes, pepper is used profusely; if white it is explicitly stated (and rather rare), whereas general references to pepper are almost certainly alluding to black pepper. ${ }^{13}$ Indeed, the medical writer Dioscorides (first century) notes that black pepper was considered the more pleasant tasting and appropriate in the making of sauces than white pepper (Materia Medica 2.189). The dominant import of black pepper is also apparent at the Red Sea ports. At Berenike black peppercorns (none have been identified as white) have been found in the thousands and in over 180 soil samples, even surpassing finds of certain staples like lentils

\footnotetext{
${ }^{13}$ For white pepper, see De re coquinaria 1.29 (salts for many ills), 5.3.2 (peas supreme style). This cook book is attributed to Apicius a famous gourmet from the reign of Tiberius (14-37 CE) who supposedly killed himself when he found out that his resources were running low and that he could no longer maintain his lavish banqueting (Seneca Ad Helviam 10). The De re coquinaria, however, actually dates to the fourth or fifth century, though it may well be based on recipes collated over a long period of time. By Tertullian's day in the latter second to early third century (Apology 3.6) the moniker Apicius could be used as a synonym for cook, hence the attribution of this cookbook. See Parker 2008: 169.
} 
(Cappers 2006: 114). By contrast long pepper is absent from the archaeobotanical record at Berenike (and has yet to be found at any other site in the Roman Empire), a fact which has been assumed to indicate a lack of seaborne trade in this item; it may be that it was not transported via the Red Sea route due to its susceptibility to mold and spoilage (Cappers 1998: 311; Cappers 2006: 116-17; Wendrich et al 2003: 69; Van der Veen 2011: 41; Sidebotham 2011: 224-5; see Appendix 2). Likewise at Myos Hormos 71 peppercorns have been found from Roman deposits (they all seem to be black pepper, mostly with the characteristic wrinkled skin), and is the most common of the recovered spices (Van der Veen 2011: 41-4).

The identification of plant remains in the archaeological record also poses a number of hurdles, the first being the fact that organic materials tends to be under-represented due to natural decay. This material often survives best in hyper-arid or anaerobic (oxygen-starved) conditions. An example of the former can be seen at the Red Sea ports of Myos Hormos and Berenike where very dry conditions have permitted organic material, including charred or desiccated plant remains, papyri, rope, and textiles, to survive (Wendrich 2000: 250). ${ }^{14}$ Likewise Roman period peppercorn finds in north-western Europe (Germany, Britain and France) have all been found in waterlogged (anaerobic) conditions (Cappers 2006: 119; Livarda 2011: 149-50). In addition, some plant remains can be found in mineralized form as seen at some houses in Pompeii and in the Cardo V sewer at Herculaneum due to the calcium and phosphate rich environment (Robinson and Rowan 2015: 105-6; Ciaraldi 2007: 49-51). These conditions tend to favour compact dry parts of plants, which is why nutshells, seeds, stem fragments of woody plants, and fruit stones are more prevalent than material like leaves, petals or roots (e.g. cinnamon, nard leaf, malabathrum), and liquid secretions (oil, gum, resins).

\footnotetext{
${ }^{14}$ Van der Veen 2011: 16-18, notes the problem of recovering botanical material near the harbour were conditions were damp or subject to wet/dry sequences. See also Van der Veen and Morales 2017: 262.
} 
With regard to peppercorns these are usually not too difficult to identify (identification of botanical remains is based on comparison with modern seeds, fruits or other plant parts), and if the wrinkled fruit wall (see above) is still present, it makes it definitively clear that it is black pepper which has been discovered (Dalby 2000a: 91; Capper 2006: 109, 119; Van der Veen 2011: 17; Van der Veen and Tabinor 2007: 85-9). The comparative popularity and cheapness of this spice, to judge from the prices given by Pliny, may also have helped the likelihood of its recovery from the archaeological record. There was a greater change of "spillage" in its transport and not as much anxiety about small losses (and hence recovery efforts) than might have been the case with more expensive spices (Van der Veen and Morales 2015: 57; Van der Veen and Morales 2015: 275). The fact that it is less challenging to identifying this plant product in the archaeobotanical record, coupled with the confidence that can be placed in ancient literary references, makes the study of black pepper consumption in the Roman Empire less problematic than might be the case with some other spices.

When it comes to examining the contexts in which black pepper was used and the various perceptions surrounding its consumption, there is a rich array of comments in the literary sources. A whole range of texts make reference to black pepper, including culinary and medicinal texts, poetry, satire, and encyclopaedic works. These sources can sometimes give a sense of the types of people consuming this product and its popularity, but the information is often impressionistic and not quantifiable. Attention also needs to be paid to the context in which this product is being referenced, be it a moralising polemic or merely an incidental comment. ${ }^{15}$ When Pliny complained about the popularity of black pepper did he have in mind primarily the elite circles of Roman society or did he mean more widely? These types of questions are addressed in the next section.

\footnotetext{
${ }^{15}$ On the challenges of interpreting such references see Gowers 1993.
} 
Compared to this varied cultural information, statistical data is extremely lacking for ancient Rome. The types of records (ship logs, accounts, company reports) available for the study of the Portuguese Estado da Índia and the English and Dutch East India companies are severely lacking for the period we are examining. There does exist a lone fragmentary document, known as the Muziris Papyrus (mid-second century) which records part of the cargo (ivory, nard, schida) for a ship called the Hermapollon, and which was valued 1,151 Egyptian talents and 5,852 drachmas after payment of the tetarte (25\% tax), equivalent to just under $6,911,852$ sestertii - meaning its total value, pre-tax, would have been equivalent to $9,215,803$ sestertii ( $P$. Vindob G 40822 Verso; Casson 1990: 195; De Romanis 1996: 192-202; De Romanis 2012: 77-8; De Romanis 2015: 135-9; Rathbone 2000: 39-50; Morelli 2011: 206-33; Wilson 2015: 23-5). ${ }^{16}$ De Romanis has attempted to reconstruct further details from the document, by reinterpreting the faint fragmentary lettering that survives on column I of the Verso. He proposes that the ships capacity was perhaps about 625 tons, of which the black pepper took up 544 tons space, and that the value of the black pepper represented about twothirds of the entire cargo (771 Egyptian talents value out of 1,151 talents and 5,852 drachmas). ${ }^{17}$ To put this in context, that one load would theoretically have been enough to give $5-10 \mathrm{~g}$ of black pepper to every inhabitant of the Roman Empire assuming a population of 50-100 million (De Romanis 2015: 139). If this reading is correct, it strongly underlines the popularity and importance of black pepper. Also given the fact that at the height of Roman participation, dozens if not a few hundred vessels (already by the 20s BCE Strabo noted 120 vessels were sailing from Myos Hormos annually) would have brought goods from India to Egypt, the potential volume of black pepper importation may have been staggering (Geography 2.5.12).

\footnotetext{
${ }^{16}$ Rathbone 2000: 49, estimates that the financier may have had assets equivalent to 20 million sestertii.

${ }^{17}$ De Romanis 2012: 75-101 - this is about $87 \%$ of the cargo space. Contra Morelli (2011: 222-8) who argues for just under 140 tons of pepper (out of 180 tons total cargo capacity).
} 
Of course, many vessels will have varied in their cargo capacity and the ratio of different goods being transported. ${ }^{18}$

The importance of pepper imports is also made clear from the author of the Periplus. When speaking of the ports of Muziris and Nelkynda/Bekarē in southern India he states that 'very big ships' voyaged to the emporia of Limyrike (Periplus 56) - that is to say, the area largely equating to the Malabar Coast were large quantities of pepper and malabathrum could be obtained. ${ }^{19}$ The impression given by the aforementioned evidence is that black pepper was perhaps the most significant of the Indian Ocean imports, although it is highly unlikely that we will ever be in a position to known precise figures. It will not be possible to assert the volume with which a particular item was imported into the Roman Empire in a specific year.

Price data can also be very patchy, although we are very fortunate that in the Natural History Pliny the Elder provides prices for various spices and aromatics (book twelve). These prices seem to provide a good indication of the likely cost of purchasing such items in Rome around the early Flavian period when Pliny was writing. Whether they derive from prices regulated by the government is open to debate. ${ }^{20}$ Many spices and aromatics did play important roles in cuisine, medicine, and religious and funerary rituals (Sidebotham 1986: 36, 45; see also Dalby 2000b: 196). Moreover, in some circumstances the Roman government

\footnotetext{
${ }^{18}$ The harbour at Berenike had the capacity to accommodate vessels of up to $19-22 \mathrm{~m}$ width and $60-1 \mathrm{~m}$ length, suggesting ships larger than the average seen in the Mediterranean - Sidebotham 2011: 195-6. ${ }^{19}$ On this passage, its emendation, and various interpretations see De Romanis 1996: 178-9 nt. 40.

${ }^{20}$ On price regulations see Sidebotham 1986: 36 - 'If Pliny is, indeed quoting from a government decree this implies some government control of commerce and suggests that regulation was necessary to prevent prices from climbing too high; we are reminded of Diocletian's Edict of Maximum Prices two centuries later.'
} 
occasionally fixed prices as part of sumptuary measures. ${ }^{21}$ However, Pliny gives the impression that prices could fluctuate not only due to quality (cassia ranged from five to 50 denarii per libra), but also due to availability (Natural History 12.43.97). In the latter case, Pliny notes that at one point cinnamon had been subject to a $50 \%$ rise in its price after the destruction of groves by marauding barbarians (Natural History 12.32.93-4). Consequently, it is probably best to see Pliny's price figures as representing a reasonable market average for Rome in the $70 \mathrm{~s} \mathrm{CE}$ (Parker 2002: 77). The use of warehouses, like the Horrea Piperataria, to store large quantities of spices probably helped keep prices reasonably stable (Dio Cassius Roman History 72.24 (c. early third century); Houston 2003).

It is possible to put Pliny's price for black pepper in the context of the evidence we have for wages in different parts of the Roman Empire during the Principate (from the reign of Augustus into the third century). In doing so we can assess how much potential income the purchase of a particular amount of black pepper may take up. This is tentatively done in the third section of this paper but with the strong caveat that wage data is particularly skewed towards Egypt, that living costs will have varied in different regions of the Roman Empire, that black pepper was likely priced slightly differently in other regions, and that it is difficult to factor in the impact of inflation (Wassink 1991: 465-493; Rathbone 2009: 299-326).

A more promising approach, which is given greater weight in this article, is the use of Diocletian's Edict of Maximum Prices. This was promulgated in $301 \mathrm{CE}$ with the intention of combating rampant inflation, especially because it was harming the soldiers who received part of their pay in the form of coined money (payment through goods in kind had become

\footnotetext{
${ }^{21}$ Suetonius Tiberius 34.1 (early to mid-second century) - Emperor Tiberius considers placing limits on costs of furniture; Tacitus Annals 3.52 (early second century) - members of the elite were concerned to hide their extravagant spending.
} 
increasingly common by this period). ${ }^{22}$ It has been possible to reconstruct part of this Edict from fragments of inscriptions, and the information contained includes detail on the wages for a number of professions as well as the maximum price the state felt it was acceptable for merchants and vendors to charge for particular goods. ${ }^{23}$ Included among this information is the maximum price for black pepper. The Edict did not last very long and there has been some debate about whether it was ever applied in the western half of the Empire, and how much it took account of regional differences. Nevertheless, the Edict at least assumes the government conceived of the Empire's economy as reasonably unified, and supposes integration at least in terms of wages (Allen 2009: 306). ${ }^{24}$ Moreover, the fact that the Edict did not stipulate specific prices, only an upper limit, may suggest regional differences were accommodated.

Rathbone argues that some of the prices for spices and aromatics in the Edict may be unreasonably low due to the fact that the prices fluctuated so much it was hard to fix realistic averages, or due to moralising intentions it was attempted to make them unprofitable to trade (Rathbone 2000: 47; Rathbone 2009: 320). This does make sense in the case of items like frankincense, set at 100 denarii communes (henceforth dc) per libra, and cassia, set at $120 \mathrm{dc}$ per libra, where the prices seem quite cheap. ${ }^{25}$ However, he notes that black pepper escapes

\footnotetext{
${ }^{22}$ Edict of Maximum Prices preface. For problems with inflation see Wassink 1991; and Corbier 1985.

${ }^{23}$ For the Edict of Maximum Prices see Giacchero 1974; and Crawford and Reynolds 1979.

${ }^{24}$ With regards to the mid-second century, Cuvigny (1996: 139-45) has noted the strong correlation between the pay-scales for Dacian miners and quarrymen at Mons Claudianus, suggesting the possibility of economic integration in terms of wages. Moreover, Kessler and Temin (2008) have argued that the Empire was thoroughly monetized with a fixed exchange rate between sestertii (Western) and drachmas (Eastern Mediterranean) and with an integrated market (at least in terms of wheat).

${ }^{25}$ The abbreviation dc (denarii communes) is used to avoid confusion with the earlier denarii of the Principate. By the late-third century the denarius had dramatically declined in terms of silver content,
} 
this fate, likely because it had become common enough not be considered a luxury. ${ }^{26}$ Indeed, black pepper, was priced at a maximum of $800 \mathrm{dc}$ per libra, equivalent to about $25.6 \mathrm{~g}$ of silver (Edict of Maximum Prices 34.67). ${ }^{27}$ This compares to Pliny's 4 denarii per libra, the notional silver equivalent is $15.13 \mathrm{~g}$ of silver (pre-64 denarii) or $12.65 \mathrm{~g}$ of silver (early-Flavian period). ${ }^{28}$ This is a potential 60-100\% increase in the "silver" cost since Pliny's time (of course, it may be the case that the full price was not always charged). Precisely how this translates into market prices is open to question, but it likely represents a real increase in cost. ${ }^{29}$ This higher price for black pepper actually makes sense in the context of direct Roman participation in the Indian Ocean trade. The first century represented a peak period in trade to judge from the archaeological and numismatic evidence, but by the third century there was a marked downturn, only to be followed by a recovery from the mid-fourth century (Young 2001: 82-6;

to the point where it was essentially billon. New forms of silver coins like the argenti had come to replace its function. The dc nevertheless continued to act as a unit of account, $1000 \mathrm{dc}$ being the equivalent of a solidus, a high purity gold coin weighing about $4.5 \mathrm{~g}$, and $100 \mathrm{dc}$ were equivalent to an argenteus, a silver coin weighing about 3g. For Roman currency values in $301 \mathrm{CE}$ see Table 1.2.

${ }^{26}$ Miller 1969: 25, also suggested that the absence of black pepper from the so-called Alexandrian Tariff (a rescript of Marcus Aurelius and Commodus detailing duties paid on various imports), unlike white and long pepper, indicates it was considered a necessity by this point - Digest 39.4.16.6-7.

${ }^{27}$ Allen 2009: 331, equates a single dc to about $0.032 \mathrm{~g}$ of silver.

${ }^{28}$ This is calculated on the basis of Julio-Claudian denarii pre-64 of about $3.9 \mathrm{~g}$ weight and $97 \%$ purity, and post-64 denarii of the first century weighing about $3.4 \mathrm{~g}$ and around $93 \%$ pure. On this higher cost see Corbier 1985: 94-5. For a tentative comparison of the prices mentioned by Pliny (first century CE) for certain plant products and those in the life of Pope Sylvester in the Liber Pontificalis (fourth century CE) see Seland 2012: 121-2.

${ }^{29}$ For theoretical comparisons of prices over time see Appendix 3. 
Whittaker 2004: 166; McLaughlin 2010: 59-60; Sidebotham 2011: 63-4, 163, 259-82; Cobb 2015b; Gurukkal 2016: 127-8). Thus it is argued that the wage data and price for black pepper from the Edict can be used with some confidence.

Indeed, the archaeobotanical record at Berenike demonstrates a consistently high level of black peppercorns across the Roman period archaeological sequence. They have been found in the majority of trenches and (for the 1994-2001 seasons) number in the many hundreds for the first to second centuries (excluding the $7.5 \mathrm{~kg}$ found in the dolium at the Great Temple), over a thousand for the fourth-fifth centuries, and again in the hundreds for the fifth century. ${ }^{30}$ Similarly, at Myos Hormos black pepper, which is by far the most common of the imported plant products, is found throughout the Roman period deposits, although, as this site is abandoned in the third century (until the Islamic period), it is less informative than Berenike (Van Der Veen 2011: 41; Van der Veen and Morales 2017: 266, 269-72). The consistently high level of finds at Berenike from the first to fifth centuries further underlines the point that the affordability of black pepper suggested by the Edict of Maximum Prices is likely valid.

\section{Perception, Consumption and Distribution}

Goods may often be considered luxurious if they fulfil most or all of the following criteria: expense, difficultly of acquisition, exotic associations, lack of necessity and rarity. ${ }^{31}$ Keay has argued that spices can be considered as such since they were not vital in any sphere (possibly excluding medicine) and therefore were attractive as status markers, being ' $r$ r]are enough to imply distinction and distinct enough to be unmistakable...' (2005: x-xi; see also Gilbert and Reynolds 2006: 29). In the case of the ancient, medieval and early modern spice trade, some

\footnotetext{
${ }^{30}$ See Cappers (2006: 161) for a table outlining black pepper finds in the record at Berenike. See also the tables of Van der Veen and Morales (2015: 57; and 2017: 270). Also Sidebotham 2011: 79.

${ }^{31}$ For a discussion of food as a luxury see van der Veen 2003: 405-27.
} 
might attach this label to products like cinnamon, cassia, cloves and nutmeg. ${ }^{32}$ However, in the case of black pepper consumption in the Roman Empire some of these categories are less obviously applicable. ${ }^{33}$ To be sure, it was obtained via Indian Ocean trade networks, entailing several months of travelling via overland and seaborne routes, involving hazardous sailing conditions, and the risks of piracy and banditry, and hence was not "easy" to acquire (Seland 2011; Cobb 2014). Also its Indian origin imbued it with exotic (and hence decadent) associations $;{ }^{34}$ there was even a tale about its collection by monkeys, although this has some parallels with Indian folklore (the vānaras) and a later description of the Maler (hill-peoples)

32 "Cinnamon" was definitely available in the Roman Empire although there has been much debate over the exact species that was imported. Some like De Romanis (1996) take the view that it was a different plant product to what we know today. Others who think it is the same offer the following identifications: Cinnamomum verum (Far East) - Groom 2002: 94; Cinnamomum zeylanicum (Sri Lanka) - Casson 1989: 122-4; Cinnamomum macrophyllum (Malaysia) - Miller 1969: 42-7, 74-7; Cinnamomum camphora (East Africa) - Manniche 1999: 17. Whether the Romans were even aware of nutmeg and mace (Myristica fragrans - nutmeg is the seed, mace the aril) is uncertain. Cappers 2006: 77-8, believes that one of the nuts referred to by Palladius (De Gentibus Indiae et Bragmanibus 1.6 - $420 \mathrm{CE}$ ) has a good chance of being nutmeg. However, this is uncertain and it is quite possible that these products did not come to Europe in a meaningful way until the late medieval and early modern periods. Cloves (cariophylu) appear to have entered the Mediterranean world by at least the Late Antique period to judge from comments by Cosmas (sixth century CE) in his Christian Topography (11.15) and information from the biography of Pope Sylvester (314-335 CE) in the Liber Pontificalis (34.20); the early lives were probably originally composed around 535-540 CE - Seland 2012.

${ }^{33}$ Purcell (2016: 75) notes that pepper in the Roman and medieval periods may fits into Crone's definition of the 'indispensable luxuries of everyday life' due to its volume of consumption and wide distribution both socially and spatially (at least among urban communities).

${ }^{34}$ For Classical literary associations of foreign foods with luxury see Nadeau 2015: 54. 
by Johann Philipp Wesdin (eighteenth century), and is, perhaps, less fanciful than the myths connected to cinnamon (from inaccessible nests) and cassia (marshes protected by frightful bats and winged serpents). ${ }^{35}$ But black pepper can hardly be described as rare given its volume of import, nor, as one of the cheapest spices mentioned by Pliny (at four denarii a libra), was it inaccessible to all but the wealthiest. ${ }^{36}$

With regard to the question of practical necessity there has been some contentious debate about the use of spices in preserving meat or covering up a rancid taste. Those who are sceptical of these ideas question why such comparatively expensive spices (compared to salt) would be used as preservatives or to cover up the taste of rotting meat (more a concern of the poor than the wealthy), and have questioned whether spices would actually be effective (Miller 1969: 10; Dalby 2000a: 156; Keay 2005: 27-8; Gilbert and Reynolds 2006: 23, 26; Freedman 2008: 3-4). On this latter point, however, recent research has suggested that spices do have preservative qualities, with antimicrobial properties killing food-spoilage micro-organisms; black pepper is less effective than other spices but it does strongly inhibit Clostridium botulinum and is a powerful antioxidant (Van der Veen 2011: 65-6). Whether the Romans ever conceived of the use of spices primarily for such preservative qualities is still open to debate.

In terms of necessity in a cultural sense, Sidebotham argues that spices and aromatics were considered as such due to the roles they played in cuisine, medicine and religious and

\footnotetext{
${ }^{35}$ Philostratus Life of Apollonius of Tyana 3.4 (c. 220-230s CE) - pepper; Herodotus Histories 3.111; Pliny Natural History 12.42 .85 - cinnamon and cassia. On the Indian folklore and early modern accounts about growing pepper see De Romanis 2015: 144-50.

${ }^{36}$ Van der Veen 2003: 407, cites the importance of a luxury being desired by many but obtained by few. In this sense black pepper falls short. It is also import to be careful about moralising authors on the issue of consumption habits, since some pagan and Christians writers condemned eating more than bread and common vegetables as "luxurious" - Nadeau 2015: 54.
} 
funerary practices (see above). While there is some value in this view, it has been recognized in much recent sociological and anthropological scholarship that labels like luxury or necessity are often static and misleading, and not always mutually exclusive (Appadurai 1986: 3-5, 16; Kopytoff 1986: 76-80. Douglas and Isherwood 1978: 72-3). The way in which black pepper was perceived in Roman society, no doubt, varied depending upon context, the quantities in which it was used and the subjective judgements of those reacting to its use (Van der Veen 2003: 406-10; Cobb 2013: 136-52). In the context of a lavish banquet, sumptuous dishes, in which black pepper was used ubiquitously (to judge from the De re coquinaria, see below), had the power to enhance a hosts prestige and, as Martial notes (Flavian period), attract guests (Epigrams 6.48; see also Seneca Epistles 19.11 (c. early 60s CE); and Pliny Natural History 12.14.29). Its exotic associations, and the potential quantity with which it was used, may have added to the sense of luxuriance, while at the same time being necessary to enhance the flavour (Van der Veen 2003: 407, 412; Freedman 2008: 6). Conversely sumptuous dining was often attacked as superfluous and harmful by Roman moralists (Seneca Ad Helviam 10; Plutarch Moralia 524 a). ${ }^{37}$ It seems that the status of black pepper was ambiguous and very much subject to context and viewpoint.

This ambiguity also extends to the medical uses of certain spices and aromatics, including black pepper. Writers such as Dioscorides, Celsus and Galen (second century) mention a range of uses for this spice from opening pores, inducing sneezing, tooth removal, coughing, eye care, to its warming and drying qualities (Celsus De Medicina 5.4.1, 5.22.9, 6.9.4-6; Dioscorides Materia Medica 2.189; Galen On the Powers and Mixtures of Simple Drugs 11.881). This versatility did not mean the use of black pepper (or other spices) in

\footnotetext{
${ }^{37}$ For the interconnection of diet and health in the ancient world see Wilkins and Hill 2006: 213-44; and Dalby 2000a: 16.
} 
medicine escaped censure. Pliny attacked the fashion for using imported Indian and Arabian products in medicine, proclaiming the virtue of traditional Italian herbs, fruits and vegetables (Natural History 24.1.4-5; Cobb 2013: 141-3).

Further debate surrounds the question of the extent to which black pepper was consumed by the wider population. There is no doubting that black pepper was popular by the Imperial and Late Antique periods. This is apparent from the De re coquinaria, which includes black pepper in $81 \%$ of the nearly 500 dishes described, even in many sweet-dishes - a notable contrast to the lack of mention in Cato's De agri cultura written several centuries earlier. ${ }^{38}$ Pliny also complained about how popular black pepper was despite its bitter taste (Natural History 12.14.29). However, does this merely reflect its popularity among the elite or a more widespread popularity? I would argue that the latter is the case, although the social data is admittedly open to interpretation. In one of Martial's satiric epigrams he notes that even the humble beet, common fare of craftsmen, was flavoured by the cook with pepper and wine (Epigrams 13.13). Are even humble craftsmen regularly eating pepper flavoured beets or is this merely a joke about the extravagance of cooks? Interestingly, it was cheaper for these craftsmen to buy a libra (323g) of pepper than it was to buy a scroll of Martial's poetry. ${ }^{39}$

The question of whether the use of pepper was lavish seems to come down to quantity. Martial complains that the amount of pepper his cook wanted to use to flavour a boar would bankrupt him (Epigrams 7.27). Yet the satirist Persius (c. late 50s to $62 \mathrm{CE}$ ) mocks the miserly man who reserves pepper for his birthday and then only sprinkles on a little (Satires 6.18-21).

\footnotetext{
${ }^{38}$ Apicius De re coquinaria $-81 \%$ of recipes include black pepper, $3 \%$ ginger, $1 \%$ rice - Van der Veen and Morales 2015: 60. The second most popular condiment after pepper is cumin - Solomon 1995: 11617.

${ }^{39}$ A roll of Martial's poetry apparently could be purchased for five denarii (1.117), which, ironically, may have been recycled as a wrapping for incense or pepper (3.2).
} 
Martial also mocks the advocate Sabellus who was overly proud of the trifling presents he received from his clients on the Saturnalia; among these gifts were a mere three-and-a-half libra of pepper and frankincense, along with items like flour and ground beans (Epigrams 4.46). ${ }^{40}$ The complaints of Pliny and the mocking of Persius and Martial must be seen in their moralising or satirical contexts, but exaggerations aside, the impressions they give are that black pepper, when used excessively, might seem lavish, but it was frequently consumed, and when used in small amounts it was far from decadent. ${ }^{41}$

This notion of commonality is certainly one that has found favour in recent scholarship. Advocates of this view argue that small quantities of some of the less expensive Indian Ocean goods, particularly spices and aromatics, were purchased from time to time by those of more limited wealth. It is suggested that cumulatively these numerous small purchases by a wider segment of the population had a notable impact on the total volume of consumption (Young 2001; McLaughlin 2010; Sidebotham 2011; Van der Veen 2011). Warmington even went so far as to argue that black pepper was an everyday commodity for well-to-do households (1928: 181-2). Young points to certain segments of society like soldiers, who, although not rich, had some disposal income, and therefore were potential consumers of products like black pepper (2001: 222-3). In support of this, Sidebotham notes that individuals did not necessarily buy a whole libra (323g) of black pepper, but could make much smaller purchases, the Vindolanda tablets (c. late first to second century CE) providing an example of this, where one tablet records a purchase of two denarii worth of pepper by a low ranking soldier based at this fort near Roman-Britain's northern frontier. Indeed, he goes so far as to state that all but the most

\footnotetext{
${ }^{40}$ Note also Martial's complain that he used to receive gifts of silver plate of Sextus, but now only receives half a libra of pepper (10.57).

${ }^{41}$ Purcell (2016: 75) notes in the case of incense that because it could be used in small quantities it could be simultaneously relatively familiar and luxurious.
} 
'destitute' could buy pepper (Sidebotham 2011: 225; see also McLaughlin 2010: 143 n.17). ${ }^{42}$ These types of small purchases of spices and aromatics can also be seen from an inscription from an atrium of a building (IX.vii.24-5) at Pompeii which provides a list of items including one as worth of incense (CIL IV 5380). This incense may be part of a list of items that needed to be purchased for the running of a bar rather than a price charged to customers (Cooley and Cooley 2014: 238-9; Monteix 2015: 220; McLaughlin 2010: 145). Either way, it indicates that it was not unusual to purchase small amounts of such a product. If the cost of this incense was similar to Pliny's three denarii per libra, then it may equal to almost five scruples $(5.6 \mathrm{~g})$ in weight.

Despite the fact that most of the surplus income in the Roman Empire was concentrated in the hands of the wealthiest elites, the "rest" in Roman society was not economically homogenous. A whole range of individuals with varying levels of income existed, both in the city of Rome itself and across the Empire, from the destitute to those who possessed a moderate degree of surplus income. Therefore, there is validity in the view that many individuals with a modest amount of surplus income may have been in a position to make small purchases of black pepper, even if only occasionally. Some quantitative calculations demonstrating the feasibility of this position are given in the next section.

However, before this it is worth looking at the archaeobotanical evidence for pepper finds in order to see what patterns can be identified. Admittedly such studies have been limited until recent times, but it is likely that future studies will enhance this picture. Indeed, despite Warmington's assertion that black pepper may have been sold in ground form, it is likely that it was often traded and stored as peppercorns since this helped retain its freshness, a practice that increases the chances of black pepper being identified during surveys and excavations

\footnotetext{
${ }^{42}$ On this tablet see Bowman and Thomas 1994: 135-41 - Tab. Vindol. II.184.
} 
(1928: 183; see also Solomon 1995: 128 n.4; Cappers 2006: 44). ${ }^{43}$ This is apparent from the De re coquinaria where the cook is repeatedly instructed to grind the pepper when making seasoning or sauces (Solomon 1995: 116).

There are three main regions where black peppercorns have been discovered and discussed in publications; the first is Egypt, the second north-western Europe, and the third the Naples region. Numerically speaking the largest finds have come from Myos Hormos and Berenike (as well as Shenshef, a satellite settlement of Berenike). ${ }^{44}$ This is, perhaps, unsurprising given the central role these Red Sea ports played in the importation of Indian Ocean goods into the Roman Empire. As already noted, thousands have been found at Berenike, especially because of the burial (late first century BCE to early first century CE) by the Great Temple (the so-called Temple of Serapis) of a large Indian storage jar (dolium) of black peppercorns weighing about $7.5 \mathrm{~kg}$ - taking up about $42 \%$ of the entire volume of the jar. ${ }^{45}$ Many charred black peppercorns have also been found associated with religious contexts at the site, suggesting some sort of ritual offering, especially as peppercorns were ground without any heating for normal culinary use (Cappers 2006: 114-16). It is unclear whether this was particularly common practice elsewhere in the Roman Empire. Seventy-one peppercorns were also found at Myos Hormos (Van der Veen 2011: 41-4).

\footnotetext{
${ }^{43}$ Indeed, in this form black pepper could still retain its aroma and flavour up to 40 years later - Livarda 2011: 155.

${ }^{44}$ On the scattering of peppercorns in the middens of Shenshef see Cappers 2006: 114.

${ }^{45}$ The large capacity of the jar and its probable Indian origin (raising the possibility that this was the original container) is likely indicative of the large volumes with which black pepper was being imported - evidently small jars, containers or sacks were not sufficient for its transport. For an image of the jar see Cappers 2006: 116.
} 
Interestingly at both Myos Hormos and Berenike, only a few finds are located in domestic contexts, but mostly they are concentrated in buildings connected with the trade or in the location where commodities were transferred from shipping to caravans (and in the case of Berenike in religious contexts) (Cappers 2006: 114; Van der Veen and Morales 2015: 5-61; Van der Veen and Morales 2017: 274-5). That said, some of this product was consumed at the Red Sea ports. An ostrakon from Myos Hormos dating to the first or early second century contains a shopping list. On this Maximus asks his brother to bring him a variety of items including, wine, vinegar and vegetables, but ending with the plea not to forget the small amount of pepper requested - peri tou piperidiou mē epilathou (Bagnall 1986 - ostrakon no. 28). Similarly, four ostraka from the fortlet Didymoi (on the Koptos-Berenike route) record the sending of pepper or requests for pepper to be sent (texts dating to c. $77-125 \mathrm{CE}$ ). ${ }^{46}$ One of these is a letter from Mokotralis to his brother Gemellus asking him to send a little pepper if he has any - penpson moi [an] ekhēs mikron peperidin (O. Did. 399; Bülow-Jacobsen 2012: 328-9; Broux 2017: 142-3). Other finds in Egypt include a single peppercorn at Roman period Qasr Ibrim (now on an island in Lake Nasser), and a few black peppercorns at Mons Claudianus, a major granodiorite quarry in the Eastern Desert (Van der Veen and HamiltonDyer 1998: 107; Van der Veen 1999: 176-7 Van der Veen 2011: 44). ${ }^{47}$

In north-western Europe many of the pepper finds seem to be associated with military sites, often around Roman border territory, and urban or commercial/transport hubs (Livarda 2011: 156). In the case of the former, there is a legionary settlement at Oberaden (c.11-8/7

\footnotetext{
${ }^{46}$ O. Did. 327, 328, 364, 399 - Bülow-Jacobsen 2012. Bülow-Jacobsen suggests that some of the pepper that reached individuals in stations along the Koptos-Berenike route may have been of the 'unofficial kind', i.e. it was (illicitly) tax-free and came directly from Berenike (p. 245).

${ }^{47}$ So far no black pepper finds have been identified at quarries of Mons Porphyrites (about 50km NNW of Mons Claudianus) - Van der Veen and Tabinor 2007: 114.
} 
BCE) where eight peppercorns (both black and white) were found in a cesspit (Kučan 1984: 52-5). A single peppercorn has been identified at Biesheim-Kunheim, west of Freiburg, which dates to the second half of the first century. This site was also on the limes and connected to a nearby garrisons (Jacomet and Schibler 2001: 65-6; Cappers 2006: 119). From a well in a Roman vicus (civilian settlement surrounding a military fort) at Hessen 12 peppercorns were found, with nine still having their wrinkled fruit wall present indicating that we are dealing with black pepper (Kreuz 1995: 70). The reference to the purchase of pepper in the aforementioned wooden tablet from the military base at Vindolanda also seems to support this picture.

In relation to urban or commercial sites, 52 peppercorns have been found in the harbour area of Straubing, probably they were lost while being unloaded (Küster 1995: 137). Likewise, a piece of lead found at Trier, near the Roman border zone with free Germany, was used as a label for eight libra of pepper, equivalent to about 2.6kg (Schwinden 1983: 22; Cappers 2006: 114). At Southwark in London, mineralized black peppercorns have been found at this important Roman administrative and trading site. ${ }^{48}$ Likewise, two mineralized black peppercorns have been found in the Cardo V sewer at Herculaneum, possibly to be connected to a large, high status apartment (II.7) that space-wise was equal to some of the atrium type houses in the town (Robinson and Rowan 2015: 114). Mineralized black peppercorns have even been identified as early as the Republican period (Phase II - fourth to first-half of second century BCE) at Pompeii in the House of Hercules' Wedding, in a later period at the House of

\footnotetext{
48 The mineralized peppercorns were found at site 23 in Southwark - Cowan et al 2009: 115. A previously made identification of a black pepper at Roman Bath has now been disproven - Van der Veen, Livarda and Hill 2007: 202.
} 
the Vestals (Phase III - second-half of second century BCE to $79 \mathrm{CE}$ ), and also in the drain associated with the latter house in Area 53 (Ciaraldi 2007: 114-15, 125, 139-40, 145, 157). ${ }^{49}$

Black pepper finds seem to be less common in rural sites unconnected to the military, paralleling the absence of other "exotic" imports, at least in Roman Britain. ${ }^{50}$ This commodity has been identified at a rural site in Lahr-Dinglingen, about 40km north of Freiburg, although even here this is situated in the vicinity of military sites (Livarda 2011: 156). It is possible that the finds of four piperatoria or pepper pots (not mills), including the famous "empress" pepper pot, at Hoxne, Suffolk (early-fifth century), may be indicative of elites living in countryside villas who consumed pepper (Van der Veen and Morales 2015: 60). ${ }^{51}$ Subsequent discoveries may change this picture of limited rural consumption, but it is not entirely surprising that places where there is a greater concentration of individuals who had disposable income (urban sites and military bases) may see more evidence of pepper consumption. This seems to be borne out from the analysis of evidence relating to purchasing power to which we shall now turn.

\section{Purchasing Power}

In order to assess how feasible it may have been for wider members of the Roman population to make regular purchases of black pepper, the approach taken by Allen in his study of Roman

49 The literary sources make it clear that as early as the second century BCE eastern influences on Roman cuisine were already beginning to have an impact - Miller 1969: 8-9.

${ }^{50}$ e.g. sesame seeds, dates, figs, peaches - Van der Veen 2008: 94, 105-6.

${ }^{51}$ See also similar finds in Bulgaria (Nocolaevo, Late Antique), France (Vienne and Chaourse, third century hoards), and possibly at Sidon (Lebanon) - Van der Veen 2011: 45. Likewise the silver piperatorium in the shape of an Ethiopian man from the Chaource treasure - Walters 1921: 38-9 no.145. In addition, two possible silver piperatoria from the House of Menander at Pompeii - M114-15; Painter 2001: 18-19, 23, 71-2, plate 25 . 
living standards is adopted here (2009; see also Scheidel 2010). ${ }^{52}$ Allen derived his data from Diocletian's Edict of Maximum prices (301 CE), a short lived attempt by the emperor to fix wages as well as prices for particular goods. He used the data from this Edict to calculate the earnings of a low-skilled day-labourer (earning $25 \mathrm{dc}$ a day and a food subsidy equal to 11.1 dc), the costs of supporting a family, and how much spare income was left over. To mitigate the difficulties of comparing price data with other periods he converted the values mentioned in the Edict into silver equivalents (Allen 2009: 329-31). ${ }^{53}$ There is no intention in this article to draw comparisons with later periods, but silver equivalent are nevertheless provided.

Allen has shown that a Roman day-labourer, working 250 days a year and earning the equivalent of $289 \mathrm{~g}$ of silver (equal to $9,025 \mathrm{dc}$ ), could reasonably maintain a family (wife and two children) at a cost of $262 \mathrm{~g}$ of silver, assuming he consumed little meat and did not purchase alcohol. ${ }^{54}$ This theoretical labourer's expenditure, which Allen labels the "barebones

\footnotetext{
${ }^{52}$ For wages and wheat costs during the Principate see Rathbone 2009.
}

53 These day-labourers included, farm labourers, camel and mule drivers, water carries, and sewer cleaners - Edict of Maximum Prices 7.1a, 17, 19, 31, 32.

${ }^{54}$ Allen (2009: 330-1) puts the daily wage, incorporating food allowance (11.1 dc), at $36.1 \mathrm{dc}$ a day; a $\mathrm{dc}$ at this point $(301 \mathrm{CE}$ ) being reckoned at $0.032 \mathrm{~g}$ of pure silver. He is conservative in his estimation of the earning potential of this "average" Roman family. First of all he assumes that only the adult male is working. Whereas Scheidel (2010: 454) rightly notes that it is possible that wives and children could also be employed in some capacity to help sustain the family. Secondly Allen conservatively assumes a 250 working-day year (employment for about $68 \%$ of the year). However, there is some justification for this assumption. Underemployment (from a "modern" perspective) at certain times of the year was a facet of rural and urban economic life in pre-industrial societies. Moreover, there were a significant number of religious festivals and celebrations throughout the Roman year. Stambaugh (1988: 225-40) notes that by the end of the Republic there were about 74 days set aside for religious ludi ("games"), 
subsistence basket" includes the cost of rent, grain, which may have been boiled (puls) rather than taken to the miller/baker (reducing cost), and a small amount of vegetables, with very little expenditure on items like meat, olive oil, clothing, lamp oil, and fuel. ${ }^{55}$ This left about $10 \%$ of his expenditure left for non-essential purchases, or $27 \mathrm{~g}$ of silver. Theoretically $27 \mathrm{~g}$ of silver is equivalent to about $844 \mathrm{dc}$ (as valued at the time of Diocletian), which notionally meant that a whole libra (323g) of pepper could be purchased at the cost of $800 \mathrm{dc}$ as stipulated in the Edict (Edict of Maximum Prices 34.67). ${ }^{56}$ This would mean about slightly less than $1 \mathrm{~g}$ of pepper consumption per day (or just shy of $10 \mathrm{~g}$ of pepper used in a meal once every two weeks). ${ }^{57}$

However, our theoretical day-labourer, like Persius' miserly man, if he consumed pepper at all is more likely to have done so on special or important occasions (family celebrations, life milestones, funerary banquets), and therefore instead of buying a whole libra,

with further ludi being added during the Principate. For our purposes the adoption of a conservative 250 working-day year, and the assumption that only one adult (in a family of four) is economically active, strengthens any conclusions about theoretical surplus incomes and abilities to purchase black pepper. ${ }^{55}$ For these calculations see Allen 2009: 335-42.

${ }^{56}$ For calculations about the percentage of surplus income theoretically available to be expended on black pepper see Table 3.1.

57 What might be considered normal "usage", no doubt, varied depending upon the context. Unfortunately the De re coquinaria does not provide quantities in most recipes, but there are a few examples in which quantities of pepper are mentioned, including 12 scruples $(13.44 \mathrm{~g})$ in a "harmless" salad (2.110), 6 scruples (6.72g) in a vegetable and brain pudding (2.131), 3 scruples $(3.36 \mathrm{~g})$ in a cold asparagus and fig-pecker dish (2.132), 6 scruples (6.72g) in an elderberry custard or pie (2.135), 6 scruples $(6.72 \mathrm{~g})$ for sour chicken (6.238), 6 scruples $(6.72 \mathrm{~g})$ for a roast chicken recipe (6.241), and 8 scruples $(8.96 \mathrm{~g})$ for a sauce for game. These, however, are quite lavish dishes, and not necessarily reflective of a more modest use of pepper as a flavouring/condiment. 
may have occasionally purchased a scruple (1.12g or one-twelfth of an uncia) or an uncia $(27 \mathrm{~g}$, one-twelfth of a libra). In doing so he would have only spent 0.3 to $8 \%$ of his surplus income. In fact, unless deliberately used in large quantities to convey a sense of lavishness (as suggested by some of the recipes in the De re coquinaria), most people of lower or middling status would have used modest amounts of pepper as a flavouring. To put this into perspective, modern evidence for 1990-1995 show that people in developed countries were consuming around 100 to 200 grams of black pepper per year, suggesting somewhere between a third to half a gram per day. ${ }^{58}$ There is no way of knowing how this might have compared to an "ordinary" poor or middling Roman, but it was probably the case that the amount used was lower. The above calculations and comparisons are not intended to prove that an average day-labourer would have spent his surplus income on buying black pepper only that it is theoretically possible that he could have made such purchases. ${ }^{59}$ It might be assumed that more varied foods and wine would be a likelier focus of expenditure, but it is worth noting that consciousness about social prestige can lead people to forgo basic needs to spend money on "luxuries" to maintain/enhance their status (Van der Veen 2003: 408).

\footnotetext{
${ }^{58}$ Denmark was one of the highest consumers in this period (1990-1995) at 194g, with the USA at 168g, France at 138g, and Switzerland at 112g. For these figures see Ravindran 2000: 20.

59 The poor may have chosen to buy cheaper juniper berries which were a lower quality pepper substitute - Dalby 2000b: 195-96; Parker 2002: 45. Pliny (Natural History 12.14.29) notes the practice of some sharp vendors who attempt to adulterate their product with juniper berries, which has a similarly bitter, but less mature flavour. Both the wood and the fruit of juniper have long been appreciated for their aromatic resinous flavour. It is also of interest that a few juniper seeds (either Juniperus phoenicea or Juniperus oxycedrus) have been found at Shenshef (a satellite settlement of Berenike), just as some peppercorns have - Cappers 2016: 94, 152. The Juniperus phoenicea does grow in Egypt, but only in the Sinai region, and it is quite rare - Van der Veen 2011: 219.
} 
If we look at the pay and maintenance rate for other workers mentioned in the Edict, we see that a baker, blacksmith, stonemason, and carpenter earned $50 \mathrm{dc}$ a day (61.1 with food subsidy), a shipwright for sea-vessels 60 a day (71.1), a maker of terracotta figurines 75 a day (86.1), a mediocre scribe paid to write 500 lines a day would earn 100, and a teacher of Greek and Latin literature teaching twenty-five pupils a month could the equivalent of 167 a day. Assuming a 250 working-day year this equates to $15,275 \mathrm{dc}(477.4 \mathrm{~g}$ of silver), 17,775 (555.5g), 21,525 (672.7g), 25,000 (781.3g) and 41,750 (1.3kg) respectively (Edict of Maximum Prices $7.2,3,3 \mathrm{a}, 11,12,13,29,40,70)$. On the basis of the barebones subsistence basket, clearly these skilled workers had far more surplus income than the average day-labourer. However, if we instead use Allen's "respectability basket", which is more generous in terms of meat and wine rations, assume that the wheat is converted into bread, includes sufficient purchases of olive oil for food, cooking and lighting, as well as vegetables, cheese and eggs, fuel, and textiles for clothing, then the requirements to sustain a family are $516.4 \mathrm{~g}$ of silver a year. On the basis of a 250 working day year, our bakers, blacksmiths, stonemasons and carpenters fall a bit short of this, although if they were to work about 45-50 days extra they make up this short fall.

For the other professions, a 250 day working year, and consumption of the respectability basket, leaves $1221 \mathrm{dc}$ (or $39.1 \mathrm{~g}$ of silver) surplus for our shipwright, 4,884 (156.3) for the terracotta figurine worker, 8,278 (264.9g) for the mediocre scribe, and almost 24,500 (784g) for the Latin and Greek literature teachers (see Table 3.1). For these individuals who are already quite sated in their basic food and drink needs, and the acquisition of other useful sundries, the purchase of items like black pepper looks far more feasible. For the shipwright an uncia of black pepper would represent just over $5.5 \%$ of the surplus income and only about $1.4 \%$ of the terracotta figurine worker's surplus income. The mediocre scribe could buy an uncia for a mere $0.8 \%$ of his surplus income, or a libra for $9.7 \%$. In the case of the Greek or Latin teacher, he would be able to buy a whole libra of black pepper, with $3.3 \%$ of his surplus 
income, or buy five libra a year, for about $16.5 \%$ of his surplus income, enabling him to consume the equivalent of almost $4.5 \mathrm{~g}$ a day. Again these are merely hypothetical calculations not intended as assertions about actual consumption habits. Nevertheless, what they do show is that individuals who were moderately prosperous, but by no means rich, could quite comfortably make such purchases.

This picture can also be seen when examining the miscellaneous evidence for the Principate (c. Augustus to the early-third century). Unlike the detail that can be derived from the Edict (301 CE), evidence for wages and cost of items is more sporadic for this period. Young has pointed to legionaries as a segment in Roman society who could have made small purchases of some Indian Ocean imports. These soldiers earned 75 sestertii per month between the period of Augustus' reign up to $84 \mathrm{CE}$, while form $85 \mathrm{CE}$ until the end of the death of Commodus (192 CE) they earned 100 sestertii per month (Young 2001: 222-3). ${ }^{60}$ Compared to Pliny's prices for a libra of frankincense or pepper, such a purchase would represent around $1.33-1.75 \%$ of yearly income, leaving aside the problem that Pliny's figures may not be entirely reflective of prices outside the early Flavian period. However, this does not take into account the deductions made by the state to cover items like rations and footwear. Therefore the net pay of these soldiers was 594 (pre-85) and 784 (post-85) sestertii per annum (Rathbone 2009: 311). Taking Pliny's 16 sestertii (4 denarii) figure for a libra of black pepper, and assuming a first century net surplus income of 594 sestertii, this is about $2.7 \%$ of that surplus for the year. This of course assume the solider has no extra costs like sustaining a family. ${ }^{61}$

\footnotetext{
${ }^{60}$ For soldiers' wages see Suetonius Domitian 7.3; Dio Cassius Roman History 67.3.5.

${ }^{61}$ Rank-and-file soldiers strictly speaking could not have formal marriages while serving until $197 \mathrm{CE}$, although this does not mean that some did not have families. Phang (2001) notes that references to marriages appear on only $15 \%$ of inscriptions connected to soldiers. See also Tacitus (Annals 14.27.2), who notes that soldiers were unaccustomed to marrying and bringing up children.
} 
There are scattered pieces of evidence, particularly relating to Egypt, which give an indication of income for some professions and therefore tentative comparisons can be made (see Table 3.2; also Rathbone 2009). Ostraka from Mons Claudianus, a major quarry in the Eastern Desert of Egypt, reveal that quarrymen, masons and smiths working there earned 47 sestertii per month or 564 per annum, but they also received free rations of wheat and wine; hence they earnt the equivalent of about $72 \%$ of the surplus money of a second century legionary. It is very difficult to factor in the impact of inflation (usually assumed to be not too significant in Egypt prior to the late second century), and the possible cost of black pepper in Egypt at this point (it was likely higher in Rome), but on the face of it these individuals were probably in a position to have made small purchases of black pepper had they so wished (the find of a few black peppercorns at Mons Claudianus is of interest here) ${ }^{62}$ In contrast to these skilled workers, evidence from the Fayum suggests that a rural labourer working 250 days a year would on (modal) average earn about 300 sestertii (Rathbone 2009: 315). Even with lower grain costs in Egypt compared to Rome, it seems likely that purchases of black pepper would be rare (if made at all) by such individuals.

\section{Conclusion}

The status of black pepper in the Roman Empire was complex, and varied from context to context. It could be used lavishly in cuisine, particularly when spiced dishes formed part of a

\footnotetext{
${ }^{62}$ De Romanis (2012) suggests from a reading of the Muziris Papyrus that an Egyptian mina (551g) of black pepper was assessed at 6 drachmas value ( 1 Egyptian drachma $=1$ sestertius $)$ when arriving at one of the Red Sea ports. If one were to make a straight comparison with Pliny's 4 denarii (16 sestertii) per libra (323g) retail price in Rome, then it has increased six-fold from its wholesale purchase in Alexandria. Of course, the price of black pepper in Rome in the mid-second century may well have been different from the 70s CE.
} 
sumptuous banquet, and in these contexts had the power to imbue distinction and high status. Yet black pepper was not priced beyond the reach of all but the elite and seems to have been popular among a wider spectrum of the population. This popularity may have been based on the desire by those of lower social status to emulate elite consumption habits, the so called trickledown effect, but its taste also appears to have been genuinely appreciated to judge from the De re coquinaria and the comments of various moralists and satirists. ${ }^{63}$ An examination of available data for prices and wages, especially from the Edict of Maximum Prices, strongly demonstrates the feasibility of this trickledown effect. High-skilled, urban residents of the Roman Empire, and groups like soldiers, had the required surplus income to make regular, if modest, purchases of black pepper. The prominence of urban and military consumption of black pepper also appears to be confirmed by archaeobotanical finds of black peppercorns. The poorer, unskilled residents of urban centres and the rural poor are less likely to have made such purchases; in the latter case probably even less so if living in an economically underdeveloped region of the Roman Empire.

${ }^{63}$ For the trickledown effect see Van der Veen 2003: 409-10. On adapting social identity through cuisine in the Roman Empire see Jones 2007: 207-31. 


\section{Bibliography}

\section{Ancient Texts}

Cato De agri cultura.

Celsus De Medicina.

Dio Cassius Roman History.

Diodorus Siculus Library of History.

Dioscorides Materia Medica.

Galen On the Powers and Mixtures of Simple Drugs.

Herodotus Histories.

Martial Epigrams.

Persius Satires.

Philostratus Life of Apollonius of Tyana.

Pliny Natural History.

Plutarch Moralia.

Seneca Ad Helviam and Epistles.

Strabo Geography.

Tacitus Annals.

\section{Modern Scholarship}

Allen, Robert C. 2009. How Prosperous were the Romans?: Evidence from Diocletian's Price Edict (AD 301). In Quantifying the Roman Economy: Methods and Problems, ed. Alan Bowman and Andrew Wilson. Oxford: Oxford University Press: 327-45. 
Appadurai, Arjun. 1986. Introduction: Commodities and the Politics of Value. In The Social Life of Things: Commodities in Cultural Perspective, ed. Arjun Appadurai. Cambridge: Cambridge University Press: 3-63.

Bagnall, Roger S. 1986. Papyri and Ostraka from Quseir al-Qadim. Bulletin of the American Society of Papyrologists 23: 1-60.

Bernard, Paul. 1990. Vicissitudes au gré de l'histoire d'une statue en bronze d'Héraclès entre Séleucie du Tigre et la Mésène. Journal des Savants 1990/1-2: 3-68.

Bowersock, Glen W. 1989. La Mésène (Maisan) antonine. In L'Arabie préislamique et son environnement historique et culturel : actes du Colloque de Strasbourg, 24-27 juin 1987, ed. Toufic Fahd. Leiden: Brill: 159-68.

Bowman, Alan K. and David J. Thomas. 1994. The Vindolanda Writing-Tablets (Tabulae Vindolandenses II). London: British Museum Press.

Broux, Yanne. 2017. Trade Networks among the Army Camps of the Eastern Desert of Roman Egypt. In Sinews of Empire: Networks in the Roman Near East and Beyond, ed. Håkon F. Teigen and Eivind H. Seland. Oxford: Oxbow Books: 137-46.

Bülow-Jacobsen, Adam. 2012. Private Letters. In Didymoi: une garnison romaine dans le désert oriental d'Égypte. II - les textes, ed. Hélène Cuvigny. Cairo: Institut français d'archéologie orientale: 233-399.

Cappers, René T. J. 1998. Archaeobotanical Remains. In Report of the 1996 Excavations at Berenike (Egyptian Red Sea Coast) and the Survey of the Eastern Desert, ed. Steven E. Sidebotham and Willeke. Z. Wendrich. Leiden: Research School CNWS: 289-330.

— 2006. Roman Foodprints at Berenike: Archaeobotanical Evidence of Subsistence and Trade in the Eastern Desert of Egypt. Los Angeles: The Cotsen Institute of Archaeology Press.

Carson, Robert A. G. 1990. Coins of the Roman Empire. London: Routledge. 
Casevitz, Michel. 1995. "Mots Voyageurs" from India to Greece. In Athens, Aden, Arikamedu. Essays on the Interrelations between India, Arabia and the Eastern Mediterranean, ed. Marie-Françoise Boussac and Jean-François Salles. New Delhi: Manohar: 21-6.

Casson, Lionel. 1980. Rome's Trade with the East: The Sea Voyage to Africa and India. Transactions of the American Philological Association 110: 21-36.

- 1984. Egypt, Africa, Arabia, and India: Patterns of Seaborne Trade in the First Century A.D.. Bulletin of the American Society of Papyrologists 21: 39-47.

- 1989. [Introduction, Translation, and Commentary of] Periplus Maris Erythraei. Princeton: Princeton University Press.

- 1990. New Light on Maritime Loans: P. Vindob G 40822. Zeitschrift für Papyrologie und Epigraphik 84: 195-206.

Ciaraldi, Marina. 2007. People \& Plants in Ancient Pompeii: A New Approach to Urbanism from the Microscope Room. London: Accordia Research Institute.

Cobb, Matthew A. 2013. The Reception and Consumption of Eastern Goods in Roman Society. Greece \& Rome 60/1: 136-52.

- 2014. The Exchange of Goods from Italy to India during the Early Roman Empire: The Range of Travelling Times. Ancient West \& East 13: 89-116.

- 2015a. Balancing the Trade: Roman Cargo Shipments to India. Oxford Journal of Archaeology 34/2: 185-203.

- 2015b. The Chronology of Roman Trade in the Indian Ocean from Augustus to the Early Third Century CE. Journal of the Economic and Social History of the Orient 58: $362-418$.

Cooley, Alison E. and Melvin G. L. Cooley. 2014. Pompeii and Herculaneum: A Sourcebook, second edition. London: Routledge. 
Corbier, Mireille. 1985. Dévaluations et évolution des prix (Ier-IIIe siècles). Revue numismatique 27: 69-106.

Cowan, Carrie, Fiona Seeley, Angela Wardle, Andrew Westman and Lucy Wheeler. 2009. Roman Southwark Settlement and Economy: Excavations in Southwark 1973-91. London: MOLA.

Crawford, Michael and Joyce M. Reynolds. 1979. The Aezani Copy of the Prices Edict. Zeitschrift Für Papyrologie Und Epigraphik 34: 163-210.

Cuvigny, Hélène. 1996. The Amount of Wages Paid to the Quarry-Workers at Mons Claudianus. Journal of Roman Studies 86: 139-45.

Czarra, Fred. 2009. Spices: A Global History. London: Reaktion Books.

Dalby, Andrew. 2000a. Dangerous Tastes: The Story of Spices. London: University of California Press.

- 2000b. Empire of Pleasure Luxury and Indulgence in the Roman World. London: Routledge.

De Romanis, Federico. 1996. Cassia, cinnamomo, ossidiana: uomini e merci tra Oceano indiano e Mediterraneo. Rome: L'ERMA di BRETSCHNEIDER.

_ 2012. Playing Sudoku on the Verso of the 'Muziris Papyrus': Pepper, Malabathron and Tortoise Shell in the Cargo of the Hermapollon. Journal of Ancient Indian History 27: $75-101$.

- 2015. Comparative Perspectives on the Pepper Trade. In Across the Ocean: Nine Essays on Indo-Mediterranean Trade, ed. Federico De Romanis and Marco Maiuro. Leiden: Brill: $127-50$.

Douglas, Mary and Baron Isherwood. 1978. The World of Goods: Towards an Anthropology of Consumption. London: Routledge. 
Duncan-Jones, Richard. 1982. The Economy of the Roman Empire: Quantitative Studies, second edition. Cambridge: Cambridge University Press.

Durand, Caroline. 2009. The Nabataeans and Oriental Trade: Roads and Commodities (Fourth Century BC to First Century AD. Studies in the Archaeology and History of Jordan 10: 405-11.

Erim, Kenan T., Joyce Reynolds and Michael Crawford. 1971. Diocletian's Currency Reform: A New Inscription. Journal of Roman Studies 61: 171-7.

Freedman, Paul. 2008. Out of the East: Spices and the Medieval Imagination. London: Yale University Press.

Giacchero, Marta. 1974. Edictum Diocletiani et Collegarum de pretiis rerum venalium in integrum fere restitutum a Latinis Graecisque fragmentis, i-ii. Genoa: Instituto di Storia Antica e Scienze Ausiliarie.

Gilboa, Ayelet and Dvory Namdar. 2015. On the Beginnings of South Asian Spice Trade with the Mediterranean Region: A Review. Radiocarbon 57/2: 265-83.

Gilbert, Erik and Jonathan Reynolds. 2006. Trading Tastes: Commodity and Cultural Exchange to 1750. New Jersey: Pearson.

Gledhill, David. 2008. The Name of Plants. Cambridge: Cambridge University Press.

Gowers, Emily. 1993. The Loaded Table: Representations of Food in Roman Literature. Oxford: Clarendon Press.

Graser, Elsa R. 1940. The Edict of Diocletian on Maximum Prices. In An Economic Survey of Ancient Rome, V: Rome and Italy of the Empire, ed. Tenney Frank. Baltimore: John Hopkins Press: 305-421.

Gregoratti, Leonardo. 2011. A Parthian Port on the Persian Gulf: Characene and its Trade. Anabasis: Studia Classica et Orientalia 2: 209-29. 
Groom, Nigel. 1981. Frankincense and Myrrh: A Study of the Arabian Incense Trade. London: Longman.

- 2002. Trade, Incense and Perfume. In Queen of Sheba Treasures from Ancient Yemen, ed. John T. J. Simpson. London: British Museum Press: 88-101.

Gurukkal, Rajan. 2013. Classical Indo-Roman Trade: A Historiographical Reconsideration. Indian Historical Review 40/2: 181-206.

- 2016. Rethinking Classical Indo-Roman Trade: Political Economy of Eastern Mediterranean Exchange Relations. New Delhi: Oxford University Press.

Harl, Kenneth W. 1996. Coinage and the Roman Economy: 300 B.C. to A.D. 700. Baltimore: John Hopkins University Press.

Houston, George. 2003. Galen, His books, and the Horrea Piperataria at Rome. Memoirs of the American Academy in Rome 48: 45-51.

Huntingford, George W. B. 1980. [Introduction and translation of] The Periplus of the Erythraean Sea, [with some extracts from] Agatharkhides On the Erythraean Sea. London: Ashgate.

Jacomet, Stefanie and Jörg Schibler, J. 2001. Les contributions de l'archéobotanique et de l'archéozoologie à la connaissance de l'agriculture et de l'alimentation du site romain de Biesheim-Kunheim. In La frontière romaine sur le Rhin supérieur: à propos des fouilles récentes de Biesheim-Kunheim, ed. Suzanne Plouin, Michel Reddé and Céline Boutantin. Biesheim: Musée gallo-romain: 60-9.

Jones, Martin. 2007. Feasts: Why Humans Share Food. Oxford: Oxford University Press.

Keay, John. 2005: The Spice Route. London: John Murray.

Kessler, David and Peter Temin. 2008. Money and Prices in the Early Roman Empire. In The Monetary System of the Greek and Romans, ed. William V. Harris. Oxford: Oxford University Press: 137-59. 
Kopytoff, Igor. 1986. The Cultural Biography of things: Commoditization as Process. In The Social Life of Things: Commodities in Cultural Perspective, ed. Arjun Appadurai. Cambridge: Cambridge University Press: 64-91.

Kreuz, Angela. 1995. Landwirtschaft und ihre ökologischen Grundlagen in den Jahrhunderten um Christi Geburt: zum Stand der naturwissenschaftlichen Untersuchungen in Hessen. Berichte der Kommission für Archäologische Landesforschung in Hessen 3: 59-91.

Kučan, Dušanka. 1984. Der erste römerzeitliche Pfefferfund - nachgewiesen im Legionslager Oberaden (Stadt Bergkamen). Ausgrabungen und Funde in Westfalen-Lippe 2: 51-6.

Küster, Hansjörg. 1995. Postglaziale Vegetationsgeschichte Südbayerns Geobotanische Studien zur Prähistorischen Landschaftskunde. Berlin: Akademieverlag.

Livarda, Alexandra. 2011. Spicing Up Life in Northwestern Europe: Exotic Food Plant Imports in the Roman and Medieval World. Vegetation History and Archaeobotany 20: 143-64.

Mahadevan, Iravatham. 1996a. Pottery Inscriptions in Brahmi and Tamil-Brahmi. In The Ancient Port of Arikamedu: New Excavations and Researches 1989-1992. Volume One, ed. Vimala Begley. Pondicherry: École française d'Extrême-Orient: 287-315.

- 1996b. Tamil-Brãhmi Graffito. In Berenike 1995: Preliminary Report of the 1995 Excavations at Berenike (Egyptian Red Sea Coast) and the Survey of the Eastern Desert, ed. Steven E. Sidebotham and Willeke Wendrich. Leiden: CNWS publications: 205-8.

Manniche, Lise. 1999. Scared Luxuries: Fragrance, Aromatherapy, and Cosmetics in Ancient Egypt. London: Cornell University Press.

McLaughlin, Raoul. 2010. Rome and the Distance East: Trade Routes to the Ancient Lands of Arabia, India and China. London: Continuum. 
Millar, Fergus. 1998. Caravan Cities: The Roman Near East and Long-Distance Trade by Land. In Modus Operandi: Essays in Honour of Geoffrey Rickman, ed. Michel Austin, Jill Harries and Christopher Smith. London: Institute of Classical Studies: 122-37.

Miller, James I. 1969. The Spice Trade of the Roman Empire 29 B.C. to A.D. 641. London: Oxford University Press.

Monteix, Nicolas. 2015. Baking and Cooking. In A Companion to Food in the Ancient World, ed. John Wilkins and Robin Nadeau. Chichester: Wiley: 212-23.

Morelli, Federico. 2011. Dal Mar Rosso ad Alessandria: II Verso (ma anche il recto) del 'papiro di Muziris' (SB XVIII 13167). Tyche 26: 199-233.

Mukherjee, B. N. 1991. Trade and Media of Exchange in Pre-Gupta Vanga. In Coinage, Trade and Economy: Third International Colloquium, ed. Amal K. Jha. Nashik: Indian Institute of Research in Numismatic Studies: 46-51.

Nadeau, Robin. 2015. Cookery Books. In A Companion to Food in the Ancient World, ed. John Wilkins and Robin Nadeau. Chichester: Wiley: 53-8.

Painter, Kenneth S. 2001. The Insula of the Menander at Pompeii. Volume IV: The Silver Treasure. Oxford: Oxford University Press.

Parker, Grant. 2002. Ex Oriente Luxuria: Indian Commodities and Roman Experience. Journal of the Economic and Social History of the Orient 45/1: 40-95.

- 2008. The Making of Roman India. Cambridge: Cambridge University Press.

Peacock, David and Lucy Blue, ed. 2006. Myos Hormos - Quseir al-Qadim Roman and Islamic Ports on the Red Sea Volume 1: Survey and Excavations 1999-2003. Oxford: Oxbow Books.

Peacock, David, Lucy Blue, assisted by Julian Whitewright, ed. 2011. Myos Hormos - Quseir al-Qadim Roman and Islamic Ports on the Red Sea. Volume 2: Finds from the excavations 1999-2003. Oxford: Archaeopress. 
Phang, Sara E. 2001. The Marriage of Roman Soldiers (13 B.C. - A.D. 235). Leiden: Brill. Potts, Daniel T. 1990. The Arabian Gulf in Antiquity. 2 vols. Oxford: Clarendon Press.

Purcell, Nicholas. 2016. Unnecessary Dependences: Illustrating Circulation in Pre-Modern Large-Scale History. In The Prospect of Global History, ed. James Belich, John Darwin, Margret Frenz and Chris Wickham. Oxford: Oxford University Press: 65-79.

Raschke, Manfred. G. 1975. Papyrological Evidence for Ptolemaic and Roman Trade with India. In Proceedings of the XIV International Congress of Papyrologists: Oxford, 24 31 July 1974. Oxford: British Academy: 241-46.

- 1978. New Studies in Roman Commerce with the East. Aufstieg und Niedergang der Römischen Welt 9/2: 604-1378.

Rathbone, Dominic. 2000. The 'Muziris' Papyrus (SB XVIII 13167): Financing Roman Trade with India. In Alexandrian Studies in Honour of Mostafa el Abbadi, ed. Mohammed Abd-el-Ghani and Wessam A. Farag. Alexandria: Archaeological Society of Alexandria: 39-50.

- 2009. Earnings and Costs: Living Standards and the Roman Economy (First to Third Centuries AD). In Quantifying the Roman Economy: Methods and Problems, ed. Alan Bowman and Andrew Wilson. Oxford: Oxford University Press: 299-326.

Ravindran, P. N. ed. 2000. Black Pepper: piper nigrum. Amsterdam: CRC Press.

Ray, Himanshu P. 2015. Beyond Trade: Cultural Roots of India's Ocean. New Delhi: Aryan Books International.

Robinson, Mark and Erica Rowan. 2015. Roman Food Remains in Archaeology and the Contents of a Roman Sewer at Herculaneum. In A Companion to Food in the Ancient World, ed. John Wilkins and Robin Nadeau. Chichester: Wiley: 104-15.

Rougé, Jean. 1988. La navigation en mer Érythrée dans l'Antiquité. In L'Arabie et ses mers bordières, ed. Jean-François. Lyon: GS-Maison de l'Orient: 59-74. 
Salles, Jean-François. 1995. The Periplus of the Erythraean Sea and the Arab-Persian Gulf. In Athens, Aden, Arikamedu: Essays on the Interrelations between India, Arabia and the Eastern Mediterranean, ed. Marie-Françoise Boussac and Jean-François Salles. New Delhi: Manohar: 115-46.

Salomon, Richard. 1991. Epigraphic Remains of Indian Traders in Egypt. Journal of the American Oriental Society 111/4: 731-6.

Scheidel, Walter. 2010. Real Wages in Early Economies: Evidence for Living Standards from 1800 BCE to 1300 CE. Journal of the Economic and Social History of the Orient 53: 425-62.

Schwinden, Lothar. 1983. Handel mit Pfeffer und anderen Gewürzen im römischen Trier. Kurtrierisches Jahrbuch 23: 20-6.

Seland, Eivind. H. 2008. The Indian Ocean and the Globalisation of the Ancient World. Ancient West and East 7: 67-79.

- 2010. Ports and Political Power in the Periplus: Complex Societies and Maritime Trade on the Indian Ocean in the First Century AD. Oxford: BAR.

- 2011. The Persian Gulf or the Red Sea? Two Axes in Ancient Indian Ocean Trade: Where to Go and Why. World Archaeology 43/3: 398-409.

- 2012. The Liber Pontificalis and the Red Sea Trade of the Early to Mid $4^{\text {th }}$ Century AD. In Navigated Spaces, Connected Places: Proceedings of the Red Sea Project V, held at the University of Exeter, 16-19 September 2010, ed. Dionisius A. Agius, John P. Cooper, Athena Trakadas and Chiara Zazzaro. Oxford: Archaeopress.

- 2014. Archaeology of Trade in the Western Indian Ocean, 300 BC - AD 700. Journal of Archaeological Research 22: 367-402.

- 2016. Ships of the Desert, Ships of the Sea: Palmyra in the World Trade of the First Three Centuries CE. Wiesbaden: Harrassowitz Verlag. 
Sidebotham, Steven E. 1986. Roman Economic Policy in the Erythra Thalassa 30 B.C. - A.D. 217. Leiden: Brill.

- 2011. Berenike and the Ancient Maritime Spice Route. London: University of California Press.

Sidebotham, Steven E. and Willeke Z. Wendrich, ed. 2007. Berenike 1999/2000: Report on the Excavations at Berenike, Including Excavations in Wadi Kalalat and Siket, and the Survey of the Mons Smaragdus Region. Los Angeles: Cotsen Institute of Archaeology Press.

Sidebotham, Steven E. and Iwona Zych. 2011. Excavations. In Berenike 2008-2009: Report on the Excavations at Berenike, Including a Survey in the Eastern Desert, ed. Steven E. Sidebotham and Iwona Zych. Warsaw: University of Warsaw: 25-57.

- 2016. Results of the Winter 2014-2015 Excavations at Berenike Egypt \& Related Fieldwork in the Eastern Desert. Journal of Indian Ocean Archaeology 12: 1-34.

Smith, Richard L. 2009. Trade in World History. London: Taylor \& Francis.

Solomon, Jon. 1995. The Apician Sauce - Ius Apicianum. In Food in Antiquity, ed. John Wilkins, David Harvey and Mike Dobson. Exeter: University of Exeter Press: 115-31. Stambaugh, John E. 1988. The Ancient Roman City. Baltimore: John Hopkins University Press. Strauch, Ingo, ed. 2012. Foreign Sailors on Socotra: The Inscriptions and Drawings from the Cave Hoq. Bremen: Hempen Verlag.

Suresh, Sethuraman. 2004. Symbols of Trade Roman and Pseudo-Roman Objects Found in India. Delhi: Manohar.

Sutherland, Carol H. V. and Robert A. G. Carson, ed. 1984. The Roman Imperial Coinage Volume I Revised Edition from 31 BC to AD 69. London: Spink \& Son, LTD.

Tomber, Roberta. 2000. Indo-Roman Trade: The Ceramic Evidence from Egypt. Antiquity 74: 624-631. 
- 2007. Rome and Mesopotamia - Importers into India in the First Millennium AD. Antiquity 81: 972-88.

- 2008. Indo-Roman Trade: From Pots to Pepper. London: Bloomsbury.

Van der Veen, Marijke. 1999. The Food Supply to Roman Quarry Settlements. In The Exploitation of Plant Resources in Ancient Africa, ed. Marijke van der Veen. New York: Kluwer Academic / Plenum Publishers: 171-83.

- 2003. When is Food a Luxury?. World Archaeology 34/3: 405-27.

- 2008. Food as Embodied Material Culture: Diversity and Change in Plant Food Consumption in Roman Britain. Journal of Roman Archaeology 21: 83-109.

- 2011. Consumption, Trade and Innovation: Exploring the Botanical Remains from the Roman and Islamic Ports at Quseir al-Qadim, Egypt. Frankfurt: Journal of African Archaeology Monograph Series.

Van der Veen, Marijke and Sheila Hamilton-Dyer. 1998. A Life of Luxury in the Desert? The Food and Fodder Supply to Mons Claudianus. Journal of Roman Archaeology 11: 10116.

Van der Veen, Marijke, Alexandra Livarda and Alistair Hill. 2007. The Archaeobotany of Roman Britain: Current State and Identification of Research Priorities. Britannia 38: 181-210.

- 2008. New Plant Foods in Roman Britain - Dispersal and Social Access. Environmental Archaeology 13/1: 11-36.

Van der Veen, Marijke and Jacob Morales. 2015. The Roman and Islamic Spice Trade: New Archaeological Evidence. Journal of Ethnopharmacology 167: 54-63.

- 2017. Food Globalisation and the Red Sea: New Evidence from the Ancient Ports at Quseir al-Qadim, Egypt. In Human Interaction with the Environment in the Red Sea, 
ed. Dionisius A. Agius, Emad Khalil, Eleanor M. L. Scerri and Alun Williams. Leiden: Brill: 254-89.

Van der Veen, Marijke and Helen Tabinor. 2007. Food, Fodder and Fuel at Mons Porphyrites: the Botanical Evidence. In The Roman Imperial Quarries Survey and Excavation at Mons Porphyrites 1994-1998. Volume 2: The Excavations, ed. David Peacock and Valerie Maxfield. London: Egypt Exploration Society: 83-142.

Walters, Henry B. 1921. Catalogue of Silver Plate (Greek, Etruscan, Roman) in the British Museum. London: British Museum Press.

Warmington, Eric H. 1928. The Commerce between the Roman Empire and India. London: Cambridge University Press.

Wassink, Alfred. 1991. Inflation and financial policy under the Roman Empire to the Price Edict of 301 A.D.. Historia: Zeitschrift Für Alte Geschichte 40/4: 465-93.

Webb, Percy H. 1933. The Roman Imperial Coinage Volume V Part II. Spink \& Son, LTD.

Wendrich, Willeke. Z. 2000. Basketry and Matting. In Report of the 1998 Excavations at Berenike and the Survey of the Egyptian Eastern Desert, Including Excavations in Wadi Kalalat, ed. Steven E. Sidebotham and Willeke. Z. Wendrich. Leiden: CNWS Publications: 227-50.

Wendrich, Willeke Z., Roberta Tomber, Steven E. Sidebotham, James A. Harrel, René T. J. Cappers and Roger S. Bagnall. 2003. Berenike Crossroads: The Integration of Information. Journal of the Economic and Social History of the Orient 46/1: 46-87.

Whitcomb, Donald S. 1982. Roman Ceramics. In Quseir al-Qadim 1980 Preliminary Report, ed. Donald S. Whitcomb and Janet H. Johnson Malibu: ARCE Reports vol. 7: 51-115.

Whittaker, Charles R. 2004. Rome and Its Frontiers: The Dynamics of Empire. London: Routledge.

Wilkins, John M. and Shaun Hill. 2006. Food in the Ancient World. Oxford. 
Young, Gary K. 2001. Rome’s Eastern Trade: International Commerce and Imperial Policy 31 BC-AD 305. London: Routledge. 


\section{Appendix 1 - Periods and Corresponding Chronology}

\section{Broad periods}

Principate/Roman Imperial Period = the period from Augustus' sole rule in 30 BCE (strictly speaking he did not receive the honorific until 27 BC) up until the end of the Severan period in $235 \mathrm{CE}$.

Third Century Crisis = a series of internal and external political, military, and economic crises (with the occasional outbreak of epidemic disease) besetting the Roman Empire between 235 to $284 \mathrm{CE}$.

Dominate $=$ the period running from Diocletian's accession to power $(284 \mathrm{CE})$ until at least the end of the Western Roman Empire (476 CE).

Late Roman period/Late Antiquity = not a strictly defined period but could be said to broadly extend from around the latter third century CE to the early seventh century CE.

\section{Dynastic periods of the Principate}

Julio-Claudian period $=$ from 30 BCE (Augustus in sole control of Roman Empire) to $68 \mathrm{CE}$ (death of the Emperor Nero).

Flavian period $=$ from the triumph of the forces of Vespasian in the civil war (December 69 CE) up until the death of Domitian (96 CE).

Nervan-Antonine period $=$ from the accession of Nerva $(96 \mathrm{CE})$ to the death of Commodus (192 CE).

Severan period $=$ from the accession of Septimius Severus $(193 \mathrm{CE}-$ defeat of all opposition by $197 \mathrm{CE}$ ) to the death of Severus Alexander (235 CE). 


\section{Appendix 2 - The Consumption of Long Pepper and Trade with}

\section{the Northwest Indian Subcontinent}

The absence of long pepper in the archaeological record at the Red Sea ports, and, indeed, at other sites within the Roman Empire is striking. There is no reason to doubt that it was imported into the Roman Empire, otherwise Pliny's (Natural History 12.14.26-29) statement that it costs 15 denarii per libra would make no sense. Also it is included among the taxable products mentioned in the imperial rescript of Marcus Aurelius and Commodus, often referred to as the Alexandrian Tariff. ${ }^{64}$ Moreover, it is not infrequently included in medicaments by Roman era medical writers. ${ }^{65}$ Nevertheless, its absence in the archaeological record, especially at Berenike and Myos Hormos, is probably more than just an accident of discovery.

One factor explaining this paucity may be that it was comparatively less popular than black pepper (this does not mean it was insignificant). It was clearly used in medicine, but as noted in the main article, it does not seem to have been prevalent in cuisine. A second possible factor suggested by Sidebotham is its susceptibility to mold and spoilage, which may have made it a less attractive commodity to import via sea routes (2011: 224-5). Nevertheless, this does not mean it was never traded via the sea, for Diodorus Siculus reports that the Nabataeans were acquiring long pepper from the Gerrahaeans (context is the third century BCE), who received it as a result of the seaborne commerce via the Persian Gulf (Diodorus Siculus Library

${ }^{64}$ Digest 37.4.16.7. Not all the products in this rescript necessarily arrived into Alexandria via the Red Sea trade, as the inclusion of Persian gum, Tyrian cassia, and North African wool makes clear.

${ }^{65}$ For example, see the De Medicina of Celsus (5.18.10ff) for the use of long pepper in various emollients and its use in King Mithridates' famous antidote against poison (5.23.3). 
of History 19.94.10; Durand 2009: 408-9). ${ }^{66}$ The third factor which may offer an explanation is the nature of the trade networks.

Clearly some "Roman" merchants did travel to northwest Indian ports. The author of the Periplus strongly infers this when he notes that long pepper could be acquired at Barygaza, while Roman gold and silver money could be exchanged for a profit against the local currency (49). As informative as his statements are, however, they do not necessarily tell us the comparative intensity of contact. The archaeological and written evidence at the Red Sea ports seems to show stronger evidence for the presence of Indian merchants deriving from southern India than from the northwest. This is particularly notable when looking at the cooking wares (indicative of personal possessions rather than trade items) and the predominance of the Tamil language (mostly written in Brahmi script) from written Indian textual evidence (often found on vessel fragments or ostraka). ${ }^{67}$ By comparison few northwest Indian wares appear at the Red Sea ports (some sherds of Gujarati Organic Black Ware have been discovered) and there is a paucity of linguistic evidence (Tomber 2008: 48-9, 155-6). ${ }^{68}$ This is not to deny the existence of trade links with the northwest, but the evidence indicates that links with southern India were stronger - the region from which black pepper was acquired. Furthermore,

${ }^{66}$ Indeed, into the early centuries of the first millennium CE links between northwest India and the Persian Gulf region grew even stronger. It is entirely possible that long pepper eventually reached the Eastern Mediterranean via the Mesopotamia-Persian Gulf route. For this route see Young 2001; Gregoratti 2011; Seland 2016.

${ }^{67}$ For the archaeological evidence see Whitcomb 1982: 67; Tomber 2000: 624-30; Sidebotham and Zych 2011: 49-50; Strauch 2012: 371. For the linguistic evidence see Salomon 1991: 731-35; Mahadevan 1996a: 291; Mahadevan 1996b: 205-8. See also Wendrich et al 2003: 69, 81-2.

${ }^{68} \mathrm{By}$ comparison there is a lot of linguistic evidence from the Hoq cave on Socotra for the presence of north-western and western Indian merchants (largely in second to fourth centuries). See Strauch 2012. 
northwest India was integrated into overland trade networks, often referred to as the Silk Road(s), meaning a certain amount of long pepper may have reached the Eastern Mediterranean world by these means.

Altogether, its lower popularity, issues with its lengthy transport by sea, and the nature of the trade networks may contribute to explaining why there is little archaeological evidence for the import of long pepper, both at the Red Sea ports and across the Roman Empire. 


\section{Appendix 3 - Relative Prices Across Time}

The following indices are intended to look at the relative prices of pepper in relation to their equivalent currency/precious metal and wheat values across time. The comparison adopted here follows that utilised by Seland (2012) and Harl (1996).

First Century CE

\begin{tabular}{|c|c|c|c|}
\hline $\begin{array}{l}\text { Product (1 libra }= \\
323 \mathrm{~g})\end{array}$ & $\begin{array}{l}\text { Price in denarii } \\
\text { (based on Pliny } \\
\text { Natural History } \\
\text { book 12) }\end{array}$ & $\begin{array}{l}\text { Silver equivalent of } \\
\text { denarii (pre- } 64 \mathrm{CE}- \\
97 \% \text { pure, } 3.9 \mathrm{~g} \text {; c. } \\
64 \mathrm{CE} \text { to Flavian - } \\
93 \% \text { pure, } 3.4 \mathrm{~g} \text { ) }\end{array}$ & $\begin{array}{l}\text { Equivalent modii of } \\
\text { wheat (first century } \\
\text { prices); high - } 3 \\
\text { denarii / low - } 1 \\
\text { denarius }^{69}\end{array}$ \\
\hline Black pepper & 4 & $15.13 / 12.65 \mathrm{~g}$ & $1.33 / 4$ \\
\hline White pepper & 7 & $26.48 / 22.13 \mathrm{~g}$ & $2.33 / 7$ \\
\hline Long pepper & 15 & $56.75 / 47.43 \mathrm{~g}$ & $5 / 15$ \\
\hline
\end{tabular}

$301 \mathrm{CE}$

\begin{tabular}{|l|l|l|l|l|}
\hline $\begin{array}{l}\text { Product (1 libra } \\
=323 \mathrm{~g})\end{array}$ & $\begin{array}{l}\text { Price based on } \\
\text { Edict of } \\
\text { Maximum Prices } \\
\text { (denarii } \\
\text { communes) }\end{array}$ & $\begin{array}{l}\text { Silver equivalent } \\
\text { of dc }(0.032 \mathrm{~g} \text { of } \\
\text { silver) }\end{array}$ & $\begin{array}{l}\text { Bullion } \\
\text { equivalent }- \\
6,000 \mathrm{dc} \text { for } \\
\text { a libra of } \\
\text { refined silver }\end{array}$ & $\begin{array}{l}\text { Equivalent modii } \\
\text { of wheat }- \\
\text { modius } \\
\text { castrensis }(=1.5 \\
\text { modii) valued at } \\
100 \text { dc }- \text { hence, } 1 \\
\text { modius }=66.66 \\
\text { dc - based on } \\
\text { Edict of } \\
\text { Maximum Prices }\end{array}$ \\
\hline Black pepper & 800 & $25.6 \mathrm{~g}$ & $\begin{array}{l}\text { 7.5 times the } \\
\text { value of } \\
\text { pepper }\end{array}$ & 12 \\
\hline
\end{tabular}

${ }^{69}$ A modius equals 8.62 dry litres. Five modii was the normal monthly wheat ration for an ordinary solider during the Principate. Estimates of the cost of a modius of grain in first and early second century Rome vary (prices will have fluctuated based on the season and levels of supply in the market); most ranges are around 4 to 12 sesterii or 1 to 3 denarii. For these weight figures and price estimates see Rathbone 2009. 
Attempting to draw comparisons between the relative prices seen in the first century and those seen around the time of the Edict of Maximum Prices (301 CE) is complicated by the patchy information about wheat prices for the Principate and the issue of knowing whether the maximum price for wheat in the Edict would normally have been charged. It is quite possible that the government took account of the notable fluctuations that could occur in grain prices.

Having noted these caveats, the above attempt to compare the price of black pepper in terms of silver and wheat for both the first century and for $301 \mathrm{CE}$ shows that in relative terms black pepper may cost about a $60-100 \%$ more silver in the latter period. However, we should be cautious in assuming that this automatically equates to a $60-100 \%$ rise in terms of real prices. For the denarius was notionally pegged to the aureus at a ratio of $25: 1$ both before the reduction in its silver content (pre-64 CE) and after (post-64 CE). Since we have no real evidence for the price of pepper in Rome in the first half the first century (pre-64 CE), there is no way of knowing whether more denarii were demanded for a libra of black pepper in the 70s CE (when Pliny provides us with a price of four denarii) than had been the case a few decades earlier. Therefore it cannot necessarily be assumed that the cost of black pepper was twice as much in $301 \mathrm{CE}$ compared to the latter first century price, but only one-and-a-half times more costly than the price for the first half of the first century. Nevertheless, the disparity in the silver cost between the first century and $301 \mathrm{CE}$ almost certainly does represent a disparity in relative real terms cost, even if we cannot say precisely how much.

In terms of wheat equivalent it might be the case that one could purchase a libra $(323 \mathrm{~g})$ of pepper for the equivalent of 1.33 to 4 modii of wheat (depending upon the differing estimations by modern scholars) in the first century CE. Whereas around $301 \mathrm{CE}$, at least according to the Edict, a libra of pepper may have been the equivalent to 12 modii of wheat 
(assuming the maximum prices were charged in either case). Suggesting it was three times more expensive.

The discrepancy in terms of the price differentiation in sliver and wheat value between the two periods should led us to be cautious, especially in regard to the patchy nature of the data. Nevertheless, as noted in the main article, the fact that black pepper may have been relatively more expensive in the early fourth century than it was in the first century is not surprising given that the first century CE represented a peak phase in Roman participation in the Indian Ocean trade (this does not mean the importation of black pepper was insignificant in the early-fourth century $\mathrm{CE}$ as the archaeobotanical finds from Berenike demonstrate). If this comparison is correct, then it may be the case that black pepper was a feasible purchase for an even wider spectrum of the population in the first century CE. 